\title{
PREFACE TO THE 2007 EDITION
}

\author{
Whenever you find yourself on the side of the majority, \\ it is time to pause and reflect.
}

MARK TWAIN

I've Got the Light of Freedom was published a year after John Dittmer's Local People: The Struggle for Civil Rights in Mississippi (Illinois, 1994) and at about the same time as Adam Fairclough's Race \& Democracy: The Civil Rights Struggle in Louisiana, 1915-1972 (Georgia, 1995). In retrospect, the publication of the three books relatively close together marked a turning point of sorts in civil rights scholarship. In different ways, all three works represented a departure from what Julian Bond calls the Master Narrative of the civil rights movement. That narrative, so familiar as to constitute almost a form of civic religion, goes:

Traditionally, relationships between the races in the South were oppressive. Many Southerners were very prejudiced against Blacks. In 1954, the Supreme Court decided this was wrong. Inspired by the court, courageous Americans, Black and white, took protest to the street, in the form of sit-ins, bus boycorts, and Freedom Rides. The nonviolent protest movement, led by the brilliant and eloquent Reverend Martin Luther King, aided by a sympathetic federal government, most notably the Kennedy brothers and a born-again Lyndon Johnson, was able to make America understand racial discrimination as a moral issue. Once Americans understood that discrimination was wrong, they quickly moved to remove racial prejudice and discrimination from American life, as evidenced by 
the Civil Rights Acts of 1964 and 1965 . Dr. King was tragically slain in 1968. Fortunately, by that time the country had been changed, changed for the better in some fundamental ways. The movement was a remarkable victory for all Americans. By the r970s, Southern states where Blacks could not have voted ten years earlier were sending African Americans to Congress. Inexplicably, just as the civil rights victories were piling up, many Black Americans, under the banner of Black Power, turned their backs on American society.

One college student recently came up with an even briefer version. "One day, a nice old lady, Rosa Parks, sat down on a bus and got arrested. The next day, Martin Luther King Jr. stood up, and the Montgomery bus boycott followed. And sometime later, King delivered his famous 'I Have a Dream' speech and segregation was over." '

The last decade has witnessed a remarkable flowering of movement scholarship, much of it trying to dismantle the mainstream narrative, assertion by assertion. Scholars are questioning the top-down and triumphal underpinnings of the narrative; the overemphasis on the South as a site of struggle; the extent of nonviolence; the character of white resistance, including the idea that it was mostly a problem of the South; the continued marginalization of women; the chronology; the role of liberals; the equation of Black Power with the end of the movement; the separation between civil rights history and labor history; and the related tendency to underemphasize the economic goals of the movement. Even the language used to describe the movement is a point of contestation. Was it "segregation" or "white supremacy"? The "civil rights movement" or the "freedom struggle"? Mind you, all of this is argument among magi; popular understanding of the movement continues to be organized around Kennedy and King, around nonviolence and that speech. ${ }^{2}$

Still, even if we don't know who is listening, the scholarly literature has expanded and changed in ways that could not have been foreseen just a decade ago. Ideas which were oppositional then have a hint of a new orthodoxy about them now. Reviewing that literature is too large a task to attempt here, but we can look at some of the subsequent work on the rural South, situating Light of Freedom in the work that came after (although just doing that now can be seen as controversial). 
Among the many works which argue that the movement's beginnings need to be sought long before Brown or the Montgomery bus boycott, Paul Ortiz's Emancipation Betrayed: The Hidden History of Black Organizing and White Violence in Florida from Reconstruction to the Bloody Election of 1920 (California, 2005) is especially interesting because he couches the point in a study of a largely forgotten struggle, the post-World War I fight for the franchise and better economic conditions in Florida. He makes a very strong case for the salience of historical memory. He attributes much of the vibrancy of the Florida movement to the ability of activist leaders to ritually mobilize memories of successful Black struggle in the context of the Civil War and Reconstruction. He also stresses the importance of networks, not so much church-based groups as women's clubs, fraternal organizations, labor unions, and mutual-aid societies. Only a wave of state-sanctioned violence, in the context of utter national indifference, brought the movement to an end.

Looking at the movement in rural Louisiana over a seventy-year period, Greta De Jong's A Different Day: African American Struggles for Justice in Rural Louisiana, 1900-1970 (North Carolina, 2002) finds that the activists there always had a conception of goals broader than the Master Narrative envisions. At all points, they were concerned with economic independence, political participation, education, and safety from violence. In the I960s, CORE activists coming into the parishes she studies found people who were not so much interested in desegregating local facilities as in economic justice and the right to vote, an experience similar to that of SNCC in Mississippi. As in Mississippi, the most receptive people tended to be land-owning farmers and young people, and the most reluctant, teachers and preachers. Fraternal orders like the Masons and Knights of Pythias, which were crucial to the campaign Ortiz describes in Florida, were also significant in Louisiana. Individuals who were interested in working with CORE were not necessarily interested in its message of nonviolence: "The most common response of African Americans to the numerous drive-by shootings and bombings carried out by white supremacists in black neighborhoods was to reach for their firearms" (p. I89).

In Let The People Decide: Black Freedom and White Resistance Move- 
ments in Sunflower County, Mississippi, 1945-1986 (North Carolina, 2004), Todd Moye demonstrates that, even within a single county, the course of the movement could be very different from one town to another. He also contends that the movement almost certainly saved the county from economic disaster by creating a climate that made business investment possible. In the course of telling that story, he also tells the story of Jack Harper, a former leader of the Citizen's Council who has been repeatedly elected to public office in a Black majority county, apparently by delivering a high level of service to constituents he once tried to keep from voting. We are only beginning to think about how Southern white people understand their own adjustments to a post-movement world, a story which needs to be told at multiple levels. Joseph Crespino's In Search of Another County: Mississippi and the Conservative Counterrevolution (Princeton, forthcoming) tells one part of the story, detailing the ways political elites, after early legislative and judicial losses, began learning to cut their losses, in part by taking strategic advantage of racial antipathies in the rest of the country, saying in effect that they would desegregate the schools of Mississippi one day after the schools of New York desegregated. This kind of analysis is part of a larger, ongoing effort to see the defenders of white supremacy as something more than one-dimensional, cardboard racists.

It seems somehow fitting that white supremacists and black radicals are both being, if not rehabilitated, then at least considered through more complex lenses. The emerging literature on Black Power sees its advocates as more than hate-filled nihilists; rather, they were rational political actors whose work grew naturally out of the earlier movement and helped reshape the American political landscape, including the character of Black leadership. ${ }^{3}$ Part of what is involved in the reconsideration of Black Power is a reexamination of the idea that Civil Rights and Black Power represented fundamentally different movements, the one to be lionized -at least in retrospectthe other vilified. This involves an ongoing reexamination of the meaning of nonviolence. Rather than seeing attitudes toward violence as one of the sharpest differences between the two phases of the movement, the new scholarship emphasizes the continuities, arguing that 
philosophical commitment to nonviolence was always rare and became more so over time; that support for self-defense was always widespread; and that, in the South, many movement participants saw little tension between nonviolence as they understood it and self-defense. ${ }^{4}$ Worth Long, a SNCC activist quoted by Todd Moye, may have said it best: Black people, were, by and large, "unviolent" (p. 232).

The new Black Power literature intersects with what may be the most interesting revisionist theme, a call for more attention to African American movements for racial justice outside of the South. ${ }^{5}$ As soon as one does that, the Master Narrative is pretty much done for. Now one has to rethink the role of the church, the nature of militance, the role of left radicalism, and how McCarthyism reconfigured the movement. Looking at the North gives us a different way to think about the limits of liberalism, and of antidiscrimination as the end-all of racial policy. Some of the most interesting work, including Rhonda Williams's The Politics of Public Housing: Black Women's Struggles against Urban Inequality (Oxford, 2004) and Felicia Kornbluh's A Right to Welfare? Poor Women, Professionals, and Poverty Programs, 1935-1975 (Pennsylvania, forthcoming), focuses on the struggles of low-income urban women around welfare or public housing. They raise questions that fundamentally challenge our conception of what it means to be a citizen. What works for the sharecropper doesn't work for them. In modern America, does citizenship entail a right to some minimum level of consumption? Can you be a citizen without access to some kind of credit?

While there is no doubt that some of the most interesting work will come from this "Up South" school, the Southern vein is hardly mined out. A recent work which demonstrates that is Emilye Crosby's A Little Taste of Freedom: The Black Freedom Struggle in Claiborne County, Mississippi (North Carolina, 2005). The movement in Claiborne County, where Crosby grew up, started later than in much of the rest of the state, largely after the 1965 Voting Rights Act. Using over 140 interviews, in addition to the files of the Sovereignty Commission (Mississippi's state agency for the defense of white supremacy), FBI files, and local police files, as well as, one imagines, her personal knowledge of the county, she is able to perform the rare feat of analyzing the evolu- 
tion of a complex social movement in both the white and Black communities and of doing it at the level of personality, comparable in this respect to William Hinton's Fanshen. One can see Black people growing more confident, partly in response to the leadership of Rudy Shields, a remarkable organizer even by the standards of the Mississippi movement, and white people growing more frustrated and uncertain. One can see that at all points in the process there are divisions among both Blacks and whites that do not become part of the public transcript. Crosby offers one of the most extensive discussions available of the price individual Black people paid for their activism and of the thoroughness with which movement opponents were able to turn instruments of government to their ends, even in a county where the sheriff was relatively even-handed and respected by both sides.

There is a real temptation for bottom-up history to sing praises to the agency, courage, and wisdom of the poor and look no further. In fact, it is probably a good idea to assume that people are formed by the society they struggle against and carry some of its flaws within them. By far, the chapter of Light of Freedom which has been least commented upon by reviewers is chapter 12 with its discussion of various corruptions within the movement. To its credit, there are no plaster saints in A Little Taste of Freedom. The movement in Claiborne County relied heavily on boycotts, and Crosby describes in detail the way activists enforced discipline against Black people who failed to support the boycotts, ranging from ostracism to physical violence. That the way Black activists enforced group discipline paralleled the way the Citizen's Council enforced it was an irony lost on few. At the same time, Crosby is able to say something about how boycott violators understood what they were doing. Claiborne County is in the part of the state in which Charles Evers was most influential, and no one better reflects moral ambiguity than Evers-able to command intense loyalty from his constituents while steadily enriching himself, setting himself up as an autocrat willing to rule with force and intimidation when charisma wouldn't do, and all the while maintaining cozy relationships with the defenders of white supremacy.

Perhaps no idea was dearer to the young people who worked in Mississippi in the 1960s than the idea that they were building for the 
long haul, doing work that would continue in some form long after they themselves were no longer around. In Freedom Is a Constant Struggle: The Mississippi Civil Rights Movement and Its Legacy (Chicago, 2004), Kenneth Andrews argues that experience shows they were largely right. Comparing those Mississippi counties which developed a high level of movement infrastructure in the 1960s to those which did not, he finds that, two decades later, Blacks from movement counties still enjoyed a higher level of some public goods-more political participation, more Black officeholders, more influence over social welfare policies. 6 "In the face of resistance, movements built infrastructures and propelled changes in an array of local institutions and those efforts have had an enduring legacy in Mississippi" (p. 200).

What can be said at this point about work currently in the pipeline is that it will definitely put the Southern movement more closely in dialogue with struggles in the rest of the country, not all of them African American. It will focus on what happened in the South after national attention turned elsewhere, which will include a reevaluation of the role of federal government and market forces, as well as a reevaluation of class tensions within Black communities. If the previous wave of revisionism pushed discussion of the movement's origins back before the mid-fifties, the next will challenge the idea that the movement ended in the mid-sixties. There will be continued interest in the role the movement played in pushing the country's political center rightward. (Recall that Lyndon Johnson, signing the Voting Rights Act, commented sadly that he was signing the country over to the Republicans for the foreseeable future.) Hasan Jeffries' forthcoming work on the Alabama movement promises to be an extensive analysis of how the rural movement shaped Black Power. One hopes, with all the forthcoming work on Black Power, that it will not just use the movement as a way to think about relationships between Blacks and whites, but as a way to think about relationships among Blacks. That is one way to step outside the terms of received discourse. There is growing interest in how memories of the movement are constructed-see, especially, Renee C. Romano and Leigh Raiford, The Civil Rights Movement in American Memory (Georgia, 2006)—but little of that interest has yet focused on Black Power in any depth. Once 
we get beyond describing the obvious ways in which the movement was distorted, this is another very promising avenue of analysis.

In his interview with me, Bob Moses noted that part of what was important about SNCC is that it provided a context and a culture in which young people could grow. ${ }^{7}$ The women of SNCC are currently preparing a collection of essays (Hands on the Plow, edited by Martha Prescod Norman and Judy Richardson) that will illuminate the processes of growth. It is a remarkable collection, lyrical and self-critical in a way that memoirs seldom are, and very much in the tradition of African American humanism.

It is still true that every way of seeing is a way of not seeing. Bottomup analysis carries its own temptations, beyond the temptation of seeing only virtue in the oppressed-or, for that matter, seeing only oppression in the oppressed. Every historical parallel isn't a case of historical continuity. There really was something special about the period from the mid-fifties to the mid-sixties, if only in the degree of attention paid to race nationally and in the changed nature of acceptable public discourse. Thinking from a purely bottom-up perspective makes sense only for a limited number of questions. Understanding the consequences of the movement requires understanding national actors and institutions. ${ }^{8}$

All that acknowledged, it remains true that scholars trying to understand the world through the eyes of its subaltern classes do not bear primary responsibility for the fact that most Americans profoundly misunderstand the nature of the movement. Partly because of that misunderstanding, teaching movement history as a critique of the Master Narrative is a profoundly rewarding experience. Students of all backgrounds come away with an awareness of how perspectives embedded in the way they understand the past affect their understanding of the present. Black students, in addition, say that this kind of history makes them think differently about their forebears. They mean that they learn to think more respectfully about previous generations of Black people. They have absorbed images about the past which imply - and are more powerful because they imply, rather than state-the historical irrelevance of Black people, their massive passiv- 
ity. A history that challenges that is, of course, useful, but doing that doesn't require any embellishment. Hagiographic history is going to be attacked sooner or later. As James Baldwin noted: "To accept one's past—one's history - is not the same thing as drowning in it; it is learning how to use it. An invented past can never be used; it cracks and crumbles under the pressures of life like clay in a season of drought."' Giving young people a history that they can use doesn't require any bending of the record. Quite the contrary. The more precisely and complexly we can render the history, the longer it will be useful.

Durham, North Carolina August 2006

I. Emilye Crosby, A Little Taste of Freedom: The Black Freedom Struggle in Claiborne County, Mississippi (Chapel Hill: University of North Carolina Press, 2005), p. xiii.

2. One exception is the growing interest in Southern states in civil rights tourism. As this is written, a discussion is taking place in Philadelphia, Mississippi, on setting up a museum about the murder of Schwerner, Chaney, and Goodman, raising obvious questions about the balance berween opportunism and commemoration.

3. See Peniel Joseph, The Black Power Movement: Rethinking the Civil Rights-Black Power Era (New York: Routledge, 2006); and Peniel Joseph, Waiting 'Til the Midnight Hour: A Narrative History of Black Power in America (New York: Henry Holt, 2006). See also Jeffrey Ogbar, Black Power: Radical Politics and African American Identity (Baltimore: Johns Hopkins University Press, 2004); and Komozi Woodard, A Nation within a Nation: Amiri Baraka (Leroi Jones) and Black Power Politics (Chapel Hill: University of North Carolina Press, 1999). Of course, the best earlier literature anticipated some of the points being made in the new Black Power literature; see William Chafe, Civilities and Civil Rights: Greensboro, North Carolina, and the Black Struggle for Freedom (New York: Oxford University Press, 1980). Although it is not specifically about Black Power, Steve Estes I Am a Man: Race, Manhood, and the Civil Rights Movement (Chapel Hill: University of North Carolina Press, 2005) 
raises questions about the masculinist underpinnings of the entire movement which will be crucial to future analyses of Black Power. Stokely Carmichael's autobiography makes several contributions to this discussion; see Carmichael with Ekweume Michael Thelwell, Ready for Revolution: The Life and Struggles of Stokely Carmichael (Kwame Ture) (New York: Scribner, 2003). As to the attitude of SNCC toward Malcolm X, an issue raised in the bibliographic essay in this volume, Carmichael/Ture treats him as an exemplar in every respect. In terms of questions about intellectual gatekeeping and the shaping of historical memory, it is important to note that almost every one of the mainstream media that reviewed Carmichael's book chose a white reviewer to do it.

4. Christopher Strain, Pure Fire: Self-Defense as Activism in the Civil Rights Era (Arhens: University of Georgia Press, 2005); Akinyele Umoja, "1964: The Beginning of the End of Nonviolence in the Mississippi Freedom Movement," Radical History Review 85 (Winter 2003), pp. 20I-226; Akinyele Umoja, "We Will Shoot Back': The Natchez Model and Paramilitary Organization in the Mississippi Freedom Movement," Journal of Black Studies 32 (January 2002), pp. 267-290; Emilye J. Crosby, “'This Nonviolent Stuff Ain't No Good-It'll Get Ya Killed': Teaching about Self-Defense in the African American Freedom Struggle," in Julie Buckner Armstrong et al., eds., Teaching the American Civil Rights Movement: Freedom's Bittersweet Song (New York: Routledge, 2002); Timothy B. Tyson, Radio Free Dixie: Robert F. Williams and the Roots of Black Power (Chapel Hill: University of North Carolina Press, 1999); Lance E. Hill, The Deacons for Defense: Armed Resistance and the Civil Rights Movement (Chapel Hill: University of North Carolina Press, 2004).

5. The clarion call is Jeanne Theoharis, Komozi Woodard, and Matthew Countryman, eds., Freedom North: Black Freedom Struggles Outside the South, 1940-1980 (New York: Palgrave MacMillan, 2003); but see also Martha Biondi, To Stand and Fight: The Struggle for Civil Rights in Postwar New York City (Cambridge, Mass.: Harvard University Press, 2003); Matthew Countryman, Up South: Civil Rights and Black Power in Philadelphia (Philadelphia: University of Pennsylvania Press, 2005); and Robert Self, American Babylon: Race and the Struggle for Postwar Oakland (Princeton: Princeton University Press, 2005).

6. The pattern does not hold for school desegregation. There, counties with more movement infrastructure saw less desegregation over time, presumably a function of the fact that stronger movements generated stronger opposition in an area where the federal government wasn't going to intervene. Whether Black office-holding is in fact a collective "good" for Blacks, is, of course, a point of contestation.

7. For the Moses interview, see Charles Payne and Stephen Lawson, Debating 
the Civil Rights Movement, and ed. (Lanham, Md.: Rowman and Litrlefield, 2006).

8. Let us note, too, that some criticism of bottom-up theory and of work on the Southern movement tries to hold that work accountable for questions it is not trying to address.

9. James Baldwin, The Fire Next Time (New York: Dial Press, 1963), p. 368. 
This page intentionally left blank 